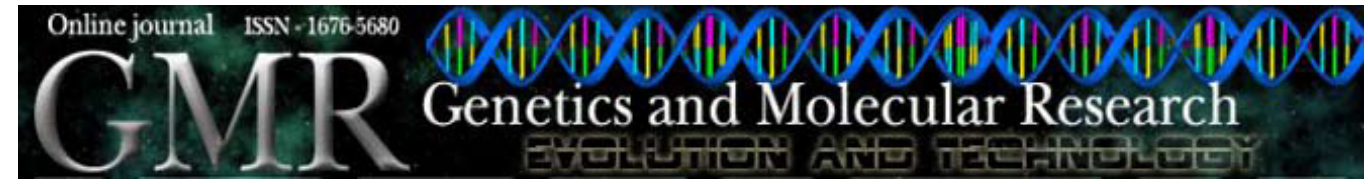

\title{
Detection of a resistance gradient to Passion fruit woodiness virus and selection of 'yellow' passion fruit plants under field conditions
}

\author{
C.B.M. Cerqueira-Silva ${ }^{1}$, C.N. Moreira $^{2}$, A.R. Figueira ${ }^{2}$, R.X. Corrêa ${ }^{1}$ \\ and A.C. Oliveira ${ }^{3}$ \\ ${ }^{1}$ Departamento de Ciências Biológicas, \\ Universidade Estadual de Santa Cruz, Ilhéus, BA, Brasil \\ ${ }^{2}$ Departamento de Fitopatologia, \\ Universidade Federal de Lavras, Lavras, MG, Brasil \\ ${ }^{3}$ Departamento de Ciências Naturais, \\ Universidade Estadual do Sudoeste da Bahia, Vitória da Conquista, BA, Brasil \\ Corresponding author: A.C. Oliveira \\ E-mail: ancaol@pq.cnpq.br
}

Genet. Mol. Res. 7 (4): 1209-1216 (2008)

Received July 25, 2008

Accepted August 29, 2008

Published November 4, 2008

\begin{abstract}
Productivity of 'yellow' passion fruit (Passiflora edulis Sims. f. flavicarpa O. Deg.) is reduced by infection with Cowpea aphidborne mosaic virus (CABMV). We examined resistance in 72 yellow passion fruit plants grown from open-pollinated commercial seed. Plants were mechanically inoculated with CABMV virus and maintained in the field in order to select contrasting genotypes for resistance. Isolates were obtained from symptomatic leaves of yellow passion fruit plants from field production in Livramento de Nossa Senhora, Bahia State and were characterized by sequencing the viral coat protein gene. Severity of leaf symptoms of the disease, evaluated through a global leaf disease index, was measured during the eighth month of growth. Morpho-agronomic variables of fruit were evaluated from months 10 to 12 . Significant linear regressions between the quantification of the leaf symptoms and the morpho-agronomic characteristics related to productivity were detected $\left(5.17 \% \leq \mathrm{R}^{2} \leq 11 \% ; 0.002 \leq \mathrm{P} \leq 0.028\right)$. Based on evaluations of fruit productivity, severity of leaf symptoms of the disease, and the application
\end{abstract}


of a selection index of $10 \%$, four contrasting groups of 'yellow' passion fruit plants considered as "resistant", "mildly resistant", "susceptible" and "extremely susceptible" in their reaction to CABMV $(0.0001<\mathrm{P}<$ $0.024)$ were selected. These plants could be useful for genetic studies and for breeding yellow passion fruit plants resistant to this disease.

Key words: CABMV; Passion fruit; Passion fruit woodiness virus; Tolerance; Susceptibility; Virology

\section{INTRODUCTION}

Passion fruit (Passifloraceae; Passiflora) originates from tropical America (Viana et al., 2003); it possesses considerable genetic variability, which should be studied, preserved and used in breeding programs (Faleiro et al., 2005). The 'yellow' passion fruit (Passiflora edulis Sims. f. flavicarpa O. Deg.) is the most widely cultivated Passiflora species in the world and predominates in the Brazilian market (Bellon et al., 2007). The main producing countries are located in South America, Brazil accounts for 70\% (491,619 metric tons) of the world's production (IBGE, 2004; Ferreira, 2005); $95 \%$ (37,252 ha) of the commercial plantings in this country consist of yellow passion fruit (IBGE, 2004). The Brazilian northeast accounts for $43 \%$ of the production, and the main producing State is Bahia, with $21 \%$ of the national production (Viana-Silva, 2003).

Production and quality of passion fruit is affected by pests and pathogens (Lima et al., 1999); Cowpea aphid-borne mosaic virus (CABMV) (Kitajima et al., 1986; Nascimento et al., 2004), the cause of Passion Fruit Woodiness Disease (PWD) in Brazil, is one of the main problems. The first register of PWD occurrence, in Brazil, was in commercial 'yellow' passion fruit plants and in $P$. alata Ait ('sweet' passion fruit) in the State of Bahia, at the end of the 1970s (Yamashiro and Chagas, 1979); later it was found in the States of Pernambuco (Loreto and Vital, 1983), Sergipe, Ceará (Kitajima et al., 1986), São Paulo (Chagas et al., 1992) and Minas Gerais (São José et al., 1994).

Pre-immunization strategies, as used in Australia by Simmonds (1959), did not protect passion fruit plants in Brazil against CABMV (Novaes and Rezende, 2003). Currently, tests are being made with transformed plants resistant to CABMV (Alfenas et al., 2005; Trevisan, 2005). However, until now, these plants have not been developed efficient gene silencing when challenged with multiple CABMV isolates.

There is little information on germplasm characterization and genetic improvement of yellow passion fruit in Brazil (Oliveira, 1980; Meletti et al., 2000; Nascimento et al., 2003; Viana et al., 2003; Farias et al., 2005a,b). Research on resistance of yellow passion fruit to CABMV are still preliminary (Tempesta Jr. et al., 2004; Leão et al., 2006; Faleiro et al., 2007; Fonseca et al., 2007). Damage and production loss caused by CABMV in yellow passion fruit have been evaluated in greenhouse production (Gioria et al., 2000).

We mechanically inoculated yellow passion fruit plants in the field with CABMV to determine their degree of resistance.

\section{MATERIAL AND METHODS}

The experiment was conducted in an experimental field of the Universidade Estadual do Sudoeste da Bahia (UESB), located in Vitória da Conquista, Bahia State 
(south latitude $14^{\circ} 53^{\prime}$ and west longitude $40^{\circ} 48^{\prime}$, average altitude $900 \mathrm{~m}$, annual average precipitation 700-800 mm, concentrated between November and March, annual average temperature $20-22^{\circ} \mathrm{C}$ ) (Instituto Nacional de Meteorologia/Ministério da Agricultura e Abastecimento). Seventy-two yellow passion fruit plants (P. edulis f. flavicarpa) were tested; these were started from seeds purchased in the central market of Vitória da Conquista.

The leaves were infected with CABMV UESB-01 isolate, by light friction of foliar limbs with a vegetal extract obtained from the maceration of leaves of yellow passion fruit showing severe symptoms of CABMV infestation, including mosaic leaf deformations and blisters, diluted 1:20 (weight:volume) in $0.02 \mathrm{M}$ potassium phosphate buffer, $\mathrm{pH}$ 7.0. This virus isolate was originally collected from yellow passion fruit plants in the producing region surrounding the city of Livramento de Nossa Senhora, Bahia. In order to minimize loss of infectivity of the viral particles, the leaves to be used as a source of inoculation were kept at $5^{\circ} \mathrm{C}$ from the time of collection until they were macerated. In order to minimize escape possibilities, inoculations were performed three times, with four- and five-month-old plant three. Three-month-old plants were transferred from plastic containers to a field plot with wire supports, with $2.5 \times 2.0 \mathrm{~m}$ spacing and drip irrigation. The plants were cultivated according to cultural treatment normally recommended for this culture.

Molecular characterization was carried out by RT-PCR, using the pair of primers CABMV-F 5' tctgatggaaaggacaaag 3' and CABMV-R 3' cgataactgtggcgagggeg 5'. These primers were used for amplification of the fragment of the coat protein gene of CABMV according to Nascimento et al. (2006), with modifications (without bases referent to enzyme restriction site, once the fragments were not cloned). The PCR were conducted according to Krause-Sakate et al. (2001) and the genomic fragment generated was used to determine percentage of identity of this PWD causal agent with other sequences of CABMV available in GenBank (http://www.ncbi.nlm.nih.gov/Genbank/).

The leaf symptoms caused by PWD were quantified in plants eight months of age; a 'global leaf disease index' (varying from 0 to 1), calculated by $\Sigma$ GS.L/TNL x HGS, where GS $=$ grade of the scale determined for each leaf, $\mathrm{L}=$ number of leaves showing to each grade of the scale, TNL = total number of leaves, and HGS = highest grade of the scale. This phytophatometric variable is an adaptation of McKinney's (1923) disease index, which consists of evaluation of the absence or presence of different levels of leaf symptoms of the disease in all leaves of the plant. The scale of grades $(0=$ without symptoms; $1=$ mild mosaic without leaf deformations; 2 = severe mosaic without leaf deformation, and $3=$ severe mosaic, blisters and leaf deformation) employed in this study to calculate the global leaf disease index was described by Novaes and Rezende (1999).

The morpho-agronomical characteristics of the fruit from the 72 yellow passion fruit plants infected with CABMV were measured bi-weekly from months 10 to the 12, including total number of the fruits, total weight of the fruits, average weight of the fruits, and average diameter of the fruits. A digital pachymeter (STARRET - 727-2001; with a precision of 0.01 $\mathrm{mm}$ ) was employed to measure fruit diameter, and a digital scale (BG 1000 with precision of $0.01 \mathrm{~g}$ ) was used for fruit weight.

Analysis of the global leaf disease index and the fruit variables consisted of standard deviation calculation, normality test, linear regression, correlation via bootstrapping $(10,000$ resamplings) and a means comparison test ( $t$-test bootstrap), using the Bioestat v4.0 software (Ayres et al., 2005). When necessary, data normalization was made through transformation, using the 'Box and Cox' test (Ayres et al., 2005). 


\section{RESULTS}

The CABMV UESB-01 isolate that we used for inoculation of yellow passion fruit plants exhibited a high percentage of identity $(>93 \%)$ with the amino acid sequences of coat protein of the strains of the CABMV available in GenBank. Considering that such molecular criteria are precise and such criteria are accepted by the International Committee of Virus Taxonomy for designation of species of Potyvirus (Van Regenmortel et al., 2000), we classified our UESB-01 sample, which caused PWD, as a strain of the CABMV.

The size and weight data are listed in Table 1. Assuming global leaf disease index as the variable predictor and the morpho-agronomic characteristics of the fruit as the dependent variables, a linear regression statistically significant was detected between the quantification of severity of the leaf symptoms of the disease with three of four characteristics evaluated [total weight of fruit, mean weight of fruit and mean diameter of fruit $\left.\left(5.17 \% \leq \mathrm{R}^{2} \leq 11 \% ; 0.002 \leq \mathrm{P} \leq 0.028\right)\right]$, a significant $\mathrm{R}^{2}$ was not identified $(\mathrm{P}=0.060)$ for the regression of global leaf disease index versus total number of fruit (Table 2). However, significant correlations $(0.154<r<0.280 ; 0.001 \leq \mathrm{P} \leq 0.033)$, by means bootstrap analysis, between the quantification of the leaf symptoms and all variables referring to the fruit productivity, including total number of fruit, were detected.

\begin{tabular}{|c|c|c|c|c|c|}
\hline Statistical parameters & TNF & TWF (kg) & AWF (g) & $\mathrm{ADF}(\mathrm{mm})$ & GLDI \\
\hline Mean & 19.2 & 3.6 & 184.9 & 80.4 & 0.60 \\
\hline Median & 13 & 3.6 & 191.3 & 82 & 0.56 \\
\hline Standard deviation & 5.76 & 1.23 & 29.9 & 3.8 & 0.097 \\
\hline Coefficient of variation & 30 & 34 & 16 & 5 & 16 \\
\hline Minimum value & $\begin{array}{c}10 \\
\text { (UESB-E27) }\end{array}$ & $\begin{array}{c}1.4 \\
\text { (UESB-E27) }\end{array}$ & $\begin{array}{c}127 \\
\text { (UESB-D2) }\end{array}$ & $\begin{array}{c}71.0 \\
\text { (UESB-E27) }\end{array}$ & $\begin{array}{c}0.35 \\
\text { (UESB-A1) }\end{array}$ \\
\hline Maximum value & $\begin{array}{c}30 \\
\text { (UESB-B2) }\end{array}$ & $\begin{array}{c}6.3 \\
\text { (UESB-B5) }\end{array}$ & $\begin{array}{c}260 \\
\text { (UESB-C3) }\end{array}$ & $\begin{array}{c}88.6 \\
\text { (UESB-E31) }\end{array}$ & $\begin{array}{c}0.84 \\
\text { (UESB-A9) }\end{array}$ \\
\hline
\end{tabular}

$\mathrm{TNF}=$ total number of fruits; $\mathrm{TWF}=$ total weight of fruit per plant; $\mathrm{AWF}=$ average weight of the fruits; $\mathrm{ADF}=$ average diameter of the fruits; GLDI = global leaf disease index $(0-1)$; UESB = identification of the genotype for each extreme value.

Table 2. Correlation and linear regression between the global leaf disease index (predictor variable) and the morpho-agronomic characteristics (dependent variables) measured in 72 yellow passion fruit plants mechanically inoculated with Cowpea aphid-borne mosaic virus isolate UESB-01.

\begin{tabular}{lcccc}
\hline Dependent variable & $r\left(\mathrm{r}^{2}\right)$ & $\mathrm{P}^{1}$ & $\left(\mathrm{R}^{2}\right)$ & $\mathrm{P}^{2}$ \\
\hline Total number of fruits & $0.154(2.4 \%)$ & 0.033 & $3.47 \%$ & 0.060 \\
Total weight of the fruits & $0.280(7.8 \%)$ & 0.001 & $11 \%$ & 0.002 \\
Average weight of the fruits & $0.259(6.7 \%)$ & 0.014 & $5.17 \%$ & 0.028 \\
Average diameter of fruits & $0.171(2.9 \%)$ & 0.006 & $7 \%$ & 0.013 \\
\hline
\end{tabular}

${ }^{1}$ Estimated value of $\mathrm{P}$ for the correlation $\left(r\right.$ and $\left.\mathrm{r}^{2}\right)$ based on 10,000 bootstrap resamplings. ${ }^{2}$ Estimated value of $\mathrm{P}$ for $\mathrm{R}^{2}$. 
The plants were selected based on the severity of the leaf symptoms due to CABMV and productivity, adopting a selection index of $10 \% ; 16$ contrasting genotypes were designated as 'resistant' (UESB-A1, UESB-B2, UESB-A21, and UESB-E31), 'mildly resistant' (UESB-A22, UESB-A12, UESB-A23, and UESB-B5), 'susceptible' (UESB-E27, UESBD10, UESB-E26, and UESB-D2), and 'extremely susceptible' (UESB-E32, UESB-E20, UESB-D8, and UESB-A9). Those genotypes, which presented lower global leaf disease index values (0.35-0.47) and higher total weight of fruit (5.57-6.30 kg) (Table 3), were considered to be resistant and mildly resistant. Similarly, those plants, which presented, concomitantly, higher values of global leaf disease index (0.72-0.84) and lower values of total weight of fruit $(1.40-4.38 \mathrm{~kg}$ ) (Table 4), were considered to be sensitive and extra-sensitive.

Table 3. Average results of morpho-agronomic characteristics of fruits and severity of leaf symptoms caused by Cowpea aphid-borne mosaic virus in eight yellow passion fruit plants selected as 'resistant' ('R') and 'moderately resistant' ('MR').

\begin{tabular}{|c|c|c|c|c|c|c|}
\hline Genotype & Resistance level & TNF & TWF (kg) & AWF (g) & $\mathrm{ADF}(\mathrm{mm})$ & GLDI \\
\hline UESB-A1 & ' $\mathrm{R}$ ' & 25 & 5.776 & 203.1 & 84.9 & 0.35 \\
\hline UESB-B2 & 'R' & 30 & 5.121 & 170.1 & 78.8 & 0.39 \\
\hline UESB-A21 & ' $\mathrm{R}$ ' & 25 & 5.401 & 207.0 & 80.7 & 0.41 \\
\hline UESB-E31 & ' $\mathrm{R}$ ' & 18 & 4.292 & 238.4 & 88.6 & 0.44 \\
\hline UESB-A22 & 'MR' & 14 & 2.814 & 187.0 & 79.0 & 0.45 \\
\hline UESB-A12 & 'MR' & 28 & 4.609 & 158.9 & 80.3 & 0.45 \\
\hline UESB-A23 & 'MR' & 25 & 5.571 & 195.0 & 85.6 & 0.46 \\
\hline UESB-B5 & 'MR' & 27 & 6.308 & 233.3 & 8.41 & 0.47 \\
\hline Mean & & 24 & 4.990 & 199.2 & 8.27 & 0.43 \\
\hline Standard deviation & & 5 & 1.01 & 25.9 & 0.33 & 0.038 \\
\hline Coefficient of variation $(\%)$ & & $20.8 \%$ & $20.3 \%$ & $13 \%$ & $4 \%$ & $8.86 \%$ \\
\hline
\end{tabular}

See Table 1 for abbreviations.

Table 4. Average results per se of morpho-agronomic characteristics of fruits and severity of leaf symptoms of the Cowpea aphid-borne mosaic virus in eight "yellow" passion flower plants selected as 'susceptible' ('S') and 'extremely susceptible' ('ES') to the UESB-01 isolated.

\begin{tabular}{|c|c|c|c|c|c|c|}
\hline Genotype & Resistance level & TNF & TWF (kg) & AWF (g) & $\mathrm{ADF}(\mathrm{mm})$ & GLDI \\
\hline UESB-E27 & 'S' & 10 & 1.400 & 139.9 & 71.0 & 0.72 \\
\hline UESB-D10 & 'S' & 15 & 2.270 & 151.3 & 76.0 & 0.72 \\
\hline UESB-E26 & 'S' & 12 & 1.964 & 163.0 & 77.0 & 0.73 \\
\hline UESB-D2 & 'S' & 22 & 2.811 & 127.0 & 80.5 & 0.73 \\
\hline UESB-E32 & 'ES' & 15 & 3.608 & 240.0 & 81.2 & 0.73 \\
\hline UESB-E20 & 'ES' & 27 & 4.388 & 162.0 & 78.5 & 0.77 \\
\hline UESB-D8 & 'ES' & 13 & 2.485 & 191.1 & 80.1 & 0.77 \\
\hline UESB-A9 & 'ES' & 20 & 3.396 & 161.7 & 78.0 & 0.84 \\
\hline Mean & & 16.7 & 2.790 & 167.0 & 77.8 & 0.75 \\
\hline Standard deviation & & 5.37 & 0.09 & 32.7 & 0.305 & 0.04 \\
\hline Coefficient of variation (\%) & & $32.11 \%$ & $32.4 \%$ & $19.5 \%$ & $3.92 \%$ & $5.3 \%$ \\
\hline
\end{tabular}

See Table 1 for abbreviations.

The group of eight yellow passion fruit plants classified as resistant and mildly resistant (Table 3) had significantly higher morpho-agronomic variables [total number of fruit $(\mathrm{P}=$ $0.016)$, total weight of fruit $(\mathrm{P}=0.002)$, mean weight of fruit $(\mathrm{P}=0.042)$, and mean diameter of fruit $(\mathrm{P}=0.0001)$ bootstrap $(10,000$ resamplings $) t$-test $]$ and significantly lower global leaf 
disease index values ( $\mathrm{P}=0.0001$; bootstrap $(10,000$ resamplings $)$-test $)$ compared to the eight yellow passion fruit plants classified as sensitive and extrasensitive (Table 4).

\section{DISCUSSION}

The high percentage of amino acid identity ( $>93 \%$ ) of the region of the coat protein (gene) of the CABMV UESB-01 isolate that we used with other identified strains of CABMV helps confirm that PWD in Brazil is caused by CABMV (Nascimento et al., 2004).

Among the four morpho-agronomic characteristics evaluated (Table 1), mean fruit diameter is very important, because consumers prefer fruit with an equatorial diameter greater than $65 \mathrm{~mm}$ (Silva and Rossi, 2005). Since mean fruit diameter ranged from $71 \mathrm{~mm}$ (genotype UESB-D10) to $88.6 \mathrm{~mm}$ (genotype UESB-E31), the germplasm that we worked with proved to be of good quality for this characteristic. Similarly, the ranges of values observed for mean fruit weight (127 g for genotype UESB-D2 and $238.4 \mathrm{~g}$ for genotype UESB-E31) are also close to published ranges for yellow passion fruit (Meletti et al., 2000; Nascimento et al., 2003).

The low linear regression values and the low correlation between gold leaf disease index and the morpho-agronomic variables of the fruit (Table 2) could be a result of high genetic variability between plants originated from commercial seeds (Meletti et al., 2000; Bellon et al., 2007) and the small and variable amount of pollen deposited on the stigma of the flowers by pollinating insects. Higher regression values for severity of leaf symptoms and fruit productivity parameters would be expected if full-sibling families from known parentals were used and/or if the flowers were manually pollinated, which would result in higher uniformity in fruit growth and development.

The significant differences found between the mean morpho-agronomic variables between the resistant/mildly resistant and sensitive/extra-sensitive passion fruit plants $(0.0001<\mathrm{P}<0.042$; bootstrap $t$-test $)$ could be due to the reduction of photosynthetic capacity because of disease (Chaves, 2002). Similar relationships between pathogen-affected leaf area and loss in the photo-assimilated production have been reported to other viral patho-systems, such as Rupestris stem pitting associated virus in wine grapes (Vitis spp; Fajardo et al., 2004) and Melon yellowing-associated virus in melons (Cucumis melo; Santos et al., 2004).

This is the first published report of inter-specific genetic variability of productivity among yellow passion fruit plants related to resistance to CABMV in production fields. Leão et al. (2006) reported on a gradient of resistance and susceptibility of yellow passion fruit plants to the CABMV under greenhouse conditions, evaluating leaf symptomatology, but they did not measure fruit production. There also have been evaluations of vegetative growth of passion fruit plants infected by CABMV under field conditions, again without evaluation of productivity (Tempesta Jr. et al., 2004). The relation between various other diseases of yellow passion fruit, including bacteriosis, anthracnosis, verrucosis and septoriosis, and fruit productivity has been evaluated previously (Junqueira et al., 2003).

We conclude that there is considerable inter-specific genetic variability in the resistance of yellow passion fruit to CABMV. We also found that severity of the disease correlates negatively and significantly with fruit production. 


\title{
ACKNOWLEDGMENTS
}

\author{
We thank Maurício Robério Silva Soares for helping cultivate the plants and CNPq for \\ a Master of Science fellowship for C.B.M. Cerqueira-Silva (\#132590/2007-7).
}

\section{REFERENCES}

Alfenas PF, Braz ASK, Torres LB, Santana EN, et al. (2005). Transgenic passionfruit expressing RNA derived from Cowpea aphid-borne mosaic virus is resistant to passionfruit woodiness disease. Fitopatol. Bras. 30: 33-38.

Ayres M, Ayres Junior M, Ayres DL and Santos AS (2005). BioEstat 4.0: Aplicações Estatísticas nas Áreas das Ciências Biomédicas. Sociedade Civil de Mamirauá, Belém.

Bellon G, Faleiro FG, Junqueira KP, Junqueira NTV, et al. (2007). Genetic variability of wild and commercial passion fruit (Passiflora edulis Sims.) accessions using RAPD markers. Rev. Bras. Frutic. 29: 124-127.

Chagas CM, Rezende JAM, Colariccio A, Piza CT Jr, et al. (1992). Ocorrência do vírus do endurecimento dos frutos do maracujazeiro (VEFM) no estado de São Paulo. Rev. Bras. Frutic. 14: 187-190.

Chaves ALR (2002). Symptoms and damage caused by virus in economic importance crops. Biológico 64: 217-219.

Fajardo TVM, Eiras M, Santos HP, Nickel O, et al. (2004). Biological and molecular detection and characterization of Rupestris stem-pitting associated virus and its effect on photosynthesis of grapevines [Detecção e caracterização biológica e molecular de Rupestris stem-pitting associated virus e seu efeito na fotossíntese de videiras]. Fitopatol. Bras. 29: 209-214.

Faleiro FG, Junqueira NTV and Braga MF (2005). Germoplasma e Melhoramento Genético do Maracujazeiro - Desafios da Pesquisa. In: Maracujá: Germoplasma e Melhoramento Genético (Faleiro FG, Junqueira NTV and Braga MF, eds.). Embrapa Cerrados, Planalatina, 187-210.

Faleiro FG, Junqueira NTV, Braga MF, Junqueira KP, et al. (2007). Cruzamentos inter-específicos e retrocruzamentos visando à resistência do maracujazeiro a doenças. In: $4^{\circ}$ Congresso Brasileiro de Melhoramento de Plantas. CDROOM, São Lourenço.

Farias MAA, Cunha MAP, Faria GA, Peixoto CP, et al. (2005a). Breeding of yellow passionfruit by stratified mass selection and competition with regional populations. Magistra 17: 142-145.

Farias MAA, Faria GA, Cunha MAP, Peixoto CP, et al. (2005b). Physical and chemical fruit characterization of yellow passionfruits of stratified mass selection cycles and local populations. Magistra 17: 83-87.

Ferreira FR (2005). Recursos Genéticos de Passiflora. In: Maracujá: Germoplasma e Melhoramento Genético (Faleiro FG, Junqueira NTV, Braga MF, eds.). Embrapa Cerrados, Planaltina, 40-52.

Fonseca KG, Faleiro FG, Junqueira NTV, Bellon G, et al. (2007). Resistência de Populações RC de Maracujazeiro ao Vírus do Endurecimento dos Frutos. In: $4^{\circ}$ Congresso Brasileiro de Melhoramento de Plantas. CD-ROOM, São Lourenço.

Gioria R, Bosquê GG, Rezende JAM, Amorim L, et al. (2000). Incidência de viroses de maracujazeiro na Alta Paulista SP e danos causados pelo "Passion fruit woodiness virus". Fitopatol. Bras. 25: 182-189.

IBGE (Instituto Brasileiro de Geografia e Estatística) (2004). Áreas Destinadas à Colheita e Colhida, Quantidade Produzida, Rendimento Médio e Valor da Produção dos Principais Produtos das Lavouras Permanentes, Segundo as Grandes Regiões e Unidades da Federação - Brasil - 2004. In: Pesquisa Agrícola Municipal. Culturas Temporárias e Permanentes, Ministério do Planejamento, Orçamento e Gestão. Instituto Brasileiro de Geografia e Estatística IBGE, Rio de Janeiro, 90.

Junqueira NTV, Anjos JRN, Silva APO, Chaves RC, et al. (2003). Reaction to diseases and yield of eleven cultivars of sour-passion fruit cultivated with no pesticides. Pesq. Agricopec. Bras. 38: 1005-1010.

Kitajima EW, Chagas CM and Crestani OA (1986). Enfermidades de etiologia viral e associadas a organismos do tipo micoplasma em maracujazeiros no Brasil. Fitopatol. Bras. 11: 405-432.

Krause-Sakate R, Mello RN, Pavan MA, Zambolim EM, et al. (2001). Molecular characterization of two Braziliam isolates of Lettuce mosaic virus with distinct biological properties. Fitopatol. Bras. 26: 153-157.

Leão RMK, Peixoto JR, Junqueira NTV, Rezende RO, et al. (2006). Reação de progênies de maracujazeiro-azedo ao vírus do endurecimento do fruto (Cowpea aphidborne mosaic virus - CABMV) em casa de vegetação. Biosci. J. 22: 87-92.

Lima AA, Carvalho JEB and Caldas RC (1999). Seletividade de herbicidas aplicados em pré-emegência para mudas de maracujá amarelo. Rev. Bras. Frutic. 21: 379-381.

Loreto TJG and Vital A (1983). Viroses e Micoplasmoses do Maracujá em Pernambuco. Informe SERDV (Serviço de Defesa Sanitária Vegetal), Recife.

McKinney HH (1923). Influence of soil temperature and moisture on infection of wheat seed lings by Helminthosporium

Genetics and Molecular Research 7 (4): 1209-1216 (2008)

CFUNPEC-RP www.funpecrp.com.br 
sativum. J. Agric. Res. 26: 159-217.

Meletti LMM, Santos RR and Minami K (2000). Breeding of yellow passion-fruit: development of the cultivar 'COMPOSTO IAC-27'. Sci. Agric. 57: 491-498.

Nascimento AVS, Souza ARR, Alfenas PF, Andrade GP, et al. (2004). Phylogenetic analysis of Potyvirus isolates causing passionfruit woodiness in Brazil. Fitopatol. Bras. 29: 378-383.

Nascimento AVS, Santana EN, Braz ASK, Alfenas PF, et al. (2006). Cowpea aphid-borne mosaic virus (CABMV) is widespread in passionfruit in Brazil and causes passionfruit woodiness disease. Arch. Virol. 151: 1797-1809.

Nascimento WMO, Tomé ATM, Oliveira MSP, Müller CA, et al. (2003). Selection of progenies of yellow passion fruit (Passiflora edulis f. flavicarpa) to fruit quality. Rev. Bras. Frutic. 25: 186-188.

Novaes QS and Rezende JAM (1999). Possível aplicação do DAS-ELISA indireto na seleção de maracujazeiro tolerante ao Passionfruit woodiness virus. Fitopatol. Bras. 24: 76-79.

Novaes QS and Rezende JAM (2003). Selected mild strains of Passion fruit woodiness virus (PWV) fail to protect preimmunized vines in Brazil. Sci. Agric. 60: 699-708.

Oliveira JC (1980). Melhoramento genético de Passiflora edulis f. flavicarpa Deg visando aumento de produtividade. Doctoral thesis, Universidade Estadual Paulista, Jaboticabal.

Santos AA, Bezerra MA, Cardoso JE, Vidal JC, et al. (2004). Effect of the melon yellowing-associated virus and whitefly on the carbon fixation, production and solid soluble total of melon fruits. Cienc. Agron. 35: 214-219.

São José AR, Rezende JAM and Costa AF (1994). Ocorrência do Vírus do Endurecimento do Fruto do Maracujazeiro no Norte do Estado de Minas Gerais. In: Congresso Brasileiro de Fruticultura, Salvador, 797.

Silva JR and Rossi AD (2005). Comercialização de Maracujá: Situação Atual, Perspectivas e Mercado de Exportação. In: Manejo no Controle do Vírus do Endurecimento dos Frutos (PWV) do Maracujazeiro (Sampaio AC, Fumis TF, Rossi AD, Almeida AM, et al, eds.). Anais, Jaboticabal, 21-36.

Simmonds JH (1959). Mild strain protection as a means of reducing losses from the Queensland woodiness virus in the passion vine. Queensl. J. Agric. Sci. 16: 371-380.

Tempesta R Jr, Peixoto JR, Medeiros FMB and Sousa MAF (2004). Desenvolvimento Vegetativo e Severidade do Vírus do Endurecimento do Fruto (Passionfruit Woodiness Virus - PWV) em 17 Genótipos de Maracujazeiro Azedo, Cultivados no Distrito Federal. In: XVIII Congresso Brasileiro de Fruticultura, Sociedade Brasileira da Fruticultura. Anais, CD, Florianópolis. Available at [http://www.sbfruti.com.br/anais_xviii_cbf/resumos/T0876-760.pdf] or [http://maracuja.cpac.embrapa.br/arquivos/artigoscompletos/2_13.pdf].

Trevisan F (2005). Transformação genética de maracujazeiro (Passiflora edulis f. flavicarpa) para resistência ao vírus do endurecimento dos frutos. Master's thesis, Escola Superior de Agricultura Luiz de Queiroz (ESALQ), Piracicaba.

Van Regenmortel MHV, Fauquet CM, Bishop DHL, Carstens EB, et al. (2000). Virus Taxonomy. Classification and Nomenclature of Viruses. Seventh Report of the International Committee on the Taxonomy of Viruses. Academic Press, New York.

Viana AP, Pereira TNS, Pereira MG, Souza MG, et al. (2003). Genetic diversity among yellow passion fruit commercial genotypes and among Passiflora species using RAPD. Rev. Bras. Frutic. 25: 489-493.

Viana-Silva TEDR, Rosa RCC, Vitorazi L, Pereira SMF, et al. (2003). Avaliação dos estádios de maturação do maracujá amarelo. I. Características físicas dos frutos e rendimento do suco. In: $6^{\circ}$ Simpósio Brasileiro sobre a Cultura do Maracujazeiro UENF/UFRRJ, Campos dos Goytacazes, 11.

Yamashiro T and Chagas CM (1979). Ocorrência de grave moléstia virótica em maracujá amarelo no Estado da Bahia. In: $5^{\circ}$ Congresso Brasileiro de Fruticultura, Sociedade Brasileira de Fruticultura, Anais, Pelotas, 915-917. 